\title{
A case report of dual infections: infection due to mycobacterium tuberculosis and mycobacterium marinum in a migrant child from Lybia to Sicily
}

\section{Kremery ${ }^{1,2}$, M. Komlosi', Z. Bacikova', S. Kruger ${ }^{1,2}$}

Original Articles

${ }^{1}$ St. Elizabeth University PhD/MSc. Tropical program, Bratislava and Nairobi, Kenya

${ }^{2}$ Gasura, Burundi and Mare Nostrum Programme, Pozallo, Italy

\section{Correspondence to:}

Maria Komlosi - St. Elizabeth Univ. tropical PhD Program Gasura, Burundi

Submitted: 19.6.2016

Revised: 23.8 .2016

Accepted: 10.9.2016

\section{Reviewers:}

J. Benca

House of hope, Phnom Penh, Cambodia

V. Namulanda

Catholic University of Eastern Africa, Nairobi, Kenya

CSWHI 2016; 7(3): 25-26; DOI 10.22359/cswhi_7_3_06 @ 2016 Clinical Social Work and Health Intervention

\section{Case}

Six year old Chadian born boy was rescued with his family after a 6 days trip in an open vessel along with 80-100 refugees from Darfour, Chad, Niger, Mali, Eritrea, Sudan, Somalia and Ethiopia(1-3). The rescue team within operation "Mare Nostrum" landed in Sicily and basic investigation screening was done on site. Because of malnutrition (BMI $<17$ ) fever and coughing, the family including the boy was scanned by regular chest X-ray and Gene-X-pert PCR type method for MTB was performed and was positive. The family was quarantined and sputum culture was positive microsopically for M. tuberculosis. Cultivation was ordered and two organismus grew in the culture, Mycobacterium marinum in 3rd week and $\mathrm{M}$. tuberculosis in a second culture in 6th week (HIV, diabetes or cancer were excluded $(4,6,7))$. Anti-TB Therapy with rifampin (both susceptible) pyrazinamid, isoniazid plus azithromycin were adjusted for 3 month however the family left qarantine after three months resulting in a loss of follow up. We assume that the child had an old M-tuberculosis infection which spread during his travel from Chad to Libya; than waiting for another two weeks in overcrowded conditions in a Libyan transit "village"; then the boat ride to get infected by an aquatic atypical mycobacterium either from bad water and substandard hygiene on the vessel; or at rescuing process from the sea (2-4). Loss of follow up is one of the major problems in therapy for those refugees who leave quarantine facilities legally or illegally (1) to travel to relatives in other EU states. 
Screening for TB, HIV and hepatitis C, and also probably for (chronic) malaria is crucial for refugees in the so called African - Malta - Italian Route through the Mediterranean Sea (1).

Location respiratory or skin manifestation of TB is easy to screen (1-3); by questionnaire for those with cough, fever, night sweats, weight loss; positive by chest X-ray; or suspected individuals positive by rapid test (Gene X-pert MTB/RIF); if positive, supervised chemotherapy for 6-months; up to 3-4 anti-TB of tests, because no real screening tests are available (3-6).

The problem is lack of screening for other than TB mycobacteria or other marine bacteria (Vibrio vulnificus etc.) (1) and malaria (4-5)

There are no available screening methods for those more rapid growing pathogens and only prolonged quarantine or supervision can help us to diagnose and properly treat those infectious diseases in refugees or "economic migrants from " the African continent $(1,3,4)$.

\section{References}

1. PRESTILEO T, DI LORENZO F, CORRAO S: Infectious Diseases among African irregular migrants in Italy. Just an individual problem? Clin. Soc. Work 2015, 5, 45
2. GÚTH, A. 2015: Pes a rehabilitácia In: Rehabilitácia ISSN 0375-0922, Vol. 52, 2015, No 3, p. 130

3. KOLÁŘOVÁ, B., KROBOT, A., HABERMANNOVÁ, P., KOLÁŘ, P., BASTLOVÁ, P. 2015: Využití představy a observace pohybu v kognitivní a pohybové rehabilitaci In: Rehabilitácia ISSN 0375-0922, Vol. 52, 2015, No 3, p. 131-139

4. KRCMERY V., KALAVSKY E: Antibiotic Resistance in "ATB free" environment. In Neuroendocrinology Letters, 2007, 28, 83, p 33-34.

5. WICZMANDYOVA D, TKACOVA L, MURGOVA A: Proceedings. Slov. Med. Univ.: The Socio Economic aspect of Migrations, ISBN 978-80-89352-47-0, pp 62-70

6. PUTEKOVA S, KABATOVA O: Nursing care for migrants in a refugee camp: Clin. Soc.Work, Health Intervention. 6. 2016.1, 73

7. SILHAROVA B, SUVADA J, FRANEKOVA M, NOGE A, MIKOLASOVA G: Malaria in hyperendemic region, Neuroendocrinology Letters 34, 2013, s1 38-43

8. SUVADA J, CZARNECKI P, TOMANEK P, JANKECHOVA M et al. Social Pathology. Warszav, 2015, pp 450

9. WICZMANDYOVA D, MURGOVA A: The life of diabetics, life with diabetes, Book Clear Michalovce ISBN 978-809711629255 .2012, pp 67. 